\title{
Managing Organizational Change through Effective Leadership: A Review from Literature
}

\author{
Nael Zuleikha Zainol, Tan Owee Kowang, Ong Choon Hee, Goh Chin Fei, \\ Baharudin Bin Kadir
}

To Link this Article: http://dx.doi.org/10.6007/IJARBSS/v11-i1/8370

DOI:10.6007/IJARBSS/v11-i1/8370

Received: 02 November 2020, Revised: 29 November 2020, Accepted: 13 December 2020

Published Online: 03 January 2021

In-Text Citation: (Zainol et al., 2021)

To Cite this Article: Zainol, N. Z., Kowang, T. O., Hee, O. C., Fei, G. C., \& Kadir, B. Bin. (2021). Managing Organizational Change through Effective Leadership: A review from Literature. International Journal of Academic Research in Business and Social Sciences, 11(1), 1-10.

\section{Copyright: @ 2021 The Author(s)}

Published by Human Resource Management Academic Research Society (www.hrmars.com)

This article is published under the Creative Commons Attribution (CC BY 4.0) license. Anyone may reproduce, distribute, translate and create derivative works of this article (for both commercial and non-commercial purposes), subject to full attribution to the original publication and authors. The full terms of this license may be seen at: http://creativecommons.org/licences/by/4.0/legalcode

\section{Vol. 11, No. 1, 2021, Pg. 1 - 10}

Full Terms \& Conditions of access and use can be found at http://hrmars.com/index.php/pages/detail/publication-ethics 


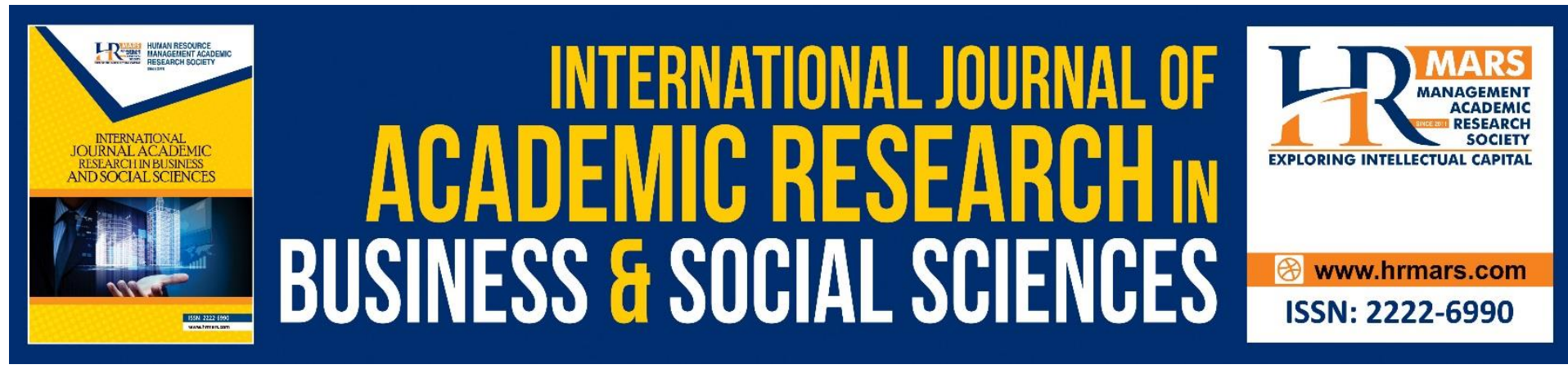

\title{
Managing Organizational Change through Effective Leadership: A Review from Literature
}

\author{
${ }^{1}$ Nael Zuleikha Zainol, ${ }^{1}$ Tan Owee Kowang, ${ }^{1}$ Ong Choon Hee, \\ ${ }^{1}$ Goh Chin Fei, ${ }^{2}$ Baharudin Bin Kadir \\ ${ }^{1}$ Azman Hashim International Business School, Universiti Teknologi Malaysia, Johor, \\ Malaysia, ${ }^{2}$ Business School, Universiti Kuala Lumpur, Malaysia \\ Email: oktan@utm.my
}

\begin{abstract}
As organizations are facing challenges in the globalization era, changes within the management in the organization must be made to ensure it can position itself in the competitive and ever changing environment. A well planned change management is crucial to ensure that change can be made to the entire organization and effectively implemented. Change management is widely known in the private sector, however, it is progressively rising in the public sector. Organizational change must be driven by a good leadership so that it is effectively and efficiently administered. This paper aimed to evaluate how prior researches had been dealing with change management in recent years taking in account of leadership styles of the managers. Well-known literatures will be discussed to outline the importance of effective leadership style for managing organizational change. The overall view from the past studies show that a good manager has the ability to drive the employees to accept change initiatives in the organization. The study recognize one of the factors to manage change in the organization that could be practically used to steer the top management, leading to corporate future direction in progressive society and vibrant economy, worth fully for further study. Keywords: Organizational Change, Change Management, Transformational Leadership
\end{abstract}

\section{Introduction}

In this 21st century, change management has been the 'flesh and blook' in both private and public sector. The impact of change is also significant in the emerging industries. All sectors need to be positively responded to current trends in terms adoption of innovative ideas and effective and efficient work processes (Barber, Donnelly \& Rizvi, 2013).

Change is a continuous and fast process that involves three phases. The first phase is unfreezing which refers to creating readiness to change by stating the importance and benefits of change. It is necessary to every individual and organization to leave the current state of comfort. Second phase is moving, where the change players have to move forward and enabling change adoption. The last phase, on the other hand is refreezing, where new changes or norms in the organization are widely accepted and routinise the changes (Awour \& Kamau, 2015). 
According to Akinbode \& Al Shuhumi (2018), to successfully manage change, there is a need for an organization to have skillful and effective leaders and they on the other hand, need to understand the change management process. They are also need to equip themselves with an appropriate leadership styles and traits so that these leaders are able to initiate and guide the change process successfully.

It is undeniably that the basic principles and practices of leadership and management have been significant all this while (Dike, Odiwe \& Ehujor, 2015; Darwish et al., 2020). However, this relationship is seen becoming more complex due to the dynamics of the 21st century organizations and the new global economy. To comply that, leaders that are able to make quick decisions, are up-to-date with the current technologies pace, great communicator between the superior and subordinates and most importantly, skilled change agents who manage to use persuasion reasons to get the followers' support on organizational change implementation. Hence, this paper aims at reviewing the relationship between transformational leadership style and managing change in organizations.

Based on the Review of Change Management in United Nations Systems Organizations by UN Joint Inspection Unit (2019), it can be concluded that 20 percent of 26 organizations, the change management has not been fully appreciated or understood in the reform, and where some organizations have done so in an ineffective method. Meanwhile, 30 percent of the reform showed evidence of incorporating the majority of the key elements of change management where it was illustrated a direct relationship between the presence of key elements of change management and the depth which they are applied.

\section{Literature Review}

The study started the discussion with organizational change, leadership and followed by focusing on transformational leadership. Finally, the role of leadership in change management was reviewed from past literature reviews.

\section{Organizational Change}

In Hussain et al (2018), organizational change refers to the explanation of the movement of an organization from a current known state to an unknown desired future state. Meanwhile, Jones (2010) defines it as the process by which organizations move from their present state to some desired future state to increase their effectiveness.

Gerwing (2016) revealed in his studies that previous researchers in the nineties, Porras and Robertson reviewed the theories and literature generally on organizational change. The researchers also conducted a deep research on the field of organizational change. There are two kinds of organizational change, which is 'planned versus unplanned change' and 'first order versus second order' change. According to Porras \& Robertson (1992), the difference between planned change is a careful verdict or process to progress the organization while unplanned change respond to external influences such as new technologies or competitors that affect an organization's main business. To face that situation, organizations must react proactively in order to response in a more adaptive manner towards planned change.

Continuous improvement can be represented by first-order change. It may cause less fundamental impact in the business as it is merely the changes or adjustments in the existing 
systems or processes. Changes in the hierarchy of an organization is one of the example. However, second-order change can be seen more drastic and crucial. It is also interrelated with to unplanned change. Porras \& Robertson (1992) termed this pattern of change as 'revolutionary change'.

In Kuipers, de Witte \& der Voet (2013) mentioned that organizational change aims at making some and obvious changes in the organization. To identify whether there is a success in an organizational change, previous researchers or stakeholders would look into the different perceptions on certain change initiatives as the term success is subjective. It was actively debated that a successful organizational change will results in organizational performance, while other researchers viewed successful change is as a result of supportive employees and their attitudes toward change.

\section{Leadership}

Leadership is defined as the ability to influence a group of employees' values, beliefs, attitudes and behavior (Ganta \& Manukonda, 2014). A leader with strong leadership skills can easily motivate and influence the employees of the organization and apply effective changes to the organization. Organizational change is a 'no-show' if there is an absence in effective leadership (Atkinson, 2015). The reason behind this is because there are no leaders that motivate and lead the organization's employees as well as provide clear direction for the organization (Hao \& Yazdanifard, 2015).

According to Bass (1985), leaders must become the change agent in promoting change by creating vision. The created vision on the other hand must be clearly defined, understandable and attainable. Leaders must possess a clear understanding of the strategic objectives for their organization, identify actions needed to achieve the objectives and conduct an analysis of the organizations existing ideologies (Belias \& Koustelios, 2014).

The role of leading changes is on a leaders' hands. Leaders help people to develop necessary skills to facilitate them in coping up with the changes in an organization (Awuor \& Kamau, 2015). An effective and strategic leaders must be attentive towards the formulation, implementation and sustaining the change efforts. In this twenty first century with the vast technological advancement, in order to make organizations gain the competitive advantage than their competitors, organizations should be more adaptive to change. Singh (2011) believes the adaptive to change can only be achieved through organizational leadership.

There are two famous types of leaderships, namely transactional and transformational leadership. In Carter, Armenakis, Field \& Mossholder (2012), a transactional leader is one who gives reward in the form of promotions, raised pay, desired change of duties and many others to those who follows. Punishment will also be given on the other hand to those who did undesirable behaviours. Meanwhile, transformational leaders change people around them by using their knowledge, expertise and vision. This will encourage full participation in changing others and the change will remain even when the leader is out of sight.

\section{Transformational Leadership}

Previous researchers, Holten \& Brenner (2015), did a study on leadership styles which are transformational and transactional and followers' change appraisal, both directly and 
indirectly through manager engagement. The researchers studied two Danish organizations, tracking the planned implementation of team organization at two different times. The findings of research is leadership styles and manager engagement is crucial in promoting such appraisal and consequently supporting positive processes and outcomes of change.

Transformational leadership may be an effective approach to enhance followers' positive appraisal of change. The entire process of change may be benefited from the long -term and short-term positive effects of managers' increased potential. Apart from that, the awareness of managers' role in communicating important information, interpreting the individual consequences, and working actively and positively towards the change may be an area of positive investment for organizations in change. Hence, a long term focus on managers' abilities to perform both transformational leadership and to engage themselves specifically in the change.

In Belias \& Koustelios (2014), strategic leadership needs to be transformational if it is aimed to serve the organization. Their studies stated that transformational leadership style is suitable for change culture because change culture needs much energy and commitment to achieve outcomes. Transformational leaders emphasize that change is accomplished through the leader's implementation of a unique vision of the organization through powerful personal characteristics designed to change internal organizational cultural norms.

Strategic leaders have the best perspective where the knowledge is concerned to see the dynamics of the culture, what should remain and what needs alteration. Past researchers mentioned in their studies that "Leaders is the art of mobilizing others to want to struggle for shared aspirations". Therefore, it is crucial for leaders to be highly skilled in change management process if they want to be a successful change agents. The main task of management nowadays is the leadership of firm change. Good strategic change leadership involves instrumental roles and big interpersonal skills. Good change leaders find out the important dimensions of change leadership. Being able to balance the roles depends mainly on whether a leader has certain qualities needed for good change leadership which supported by strong skills.

Meanwhile in Faupel \& Sub (2018), their research supported that a transformational leadership can give positive effect on employees' change-supportive behaviour during the implementation of organizational change. An effective leadership in the organization has helped to driven the motivation of the employees to support change. This has intensify the effort when the employees engaged in the process and there is an encouraging change consequences through transformational leadership within the organization. Transformational leadership is said to be the only way to achieve higher levels of valence and work engagement as it can give the true picture of the benefits and meaning of a change for employees.

In another journal article related to leadership style in organizational change management, various leadership styles have been studied that can see as a change agent or change management promoter. Mansaray (2019) reviewed various types of leadership such as authoritarian leadership, transformational leadership, laissez-faire, servant-leader, transactional leadership and many more. To his findings, the most supportive style is transformational leadership. It is hugely supported by Bass \& Riggio (2006); Eisenbach, 
Watson, \& Pillai (1999) where in order to manage organizational change, transformational leadership is the most suitable style. This leadership style is at the best position to face the trials and difficulties of the emerging administrative practices because transformational leader has the capability to drive his group in delivering and providing more than the organization expected.

In another study by Wanza \& Nkuraru (2016), the importance of strategic management in organizations nowadays has increased widely and become the most crucial elements. Strategic outcomes depend on the managerial proficiency and key management functions that involves learning to delegate, planning, organizing, clear communication, employees motivation, adaptation towards change and constant innovative ideas generation. In order to ensure change management to be effective, leaders in an organizations need to successfully motivate their teams or subordinate so that there will be high participation rate in the change management process. This, in hand is aligned with other researchers' view where every manager needs to acquire good leadership and managerial skills to induce workers to change directions (McLagan, 2002). Constant motivations and guidelines within the organization should be led by a leader or manager as it can also improves employees' performance and hence indirectly, improving organizational performance.

One of the findings of their study is leadership in an organization provides direction as a leader will influence others to follow. A positive attitude from the leaders or managers will critically affect in behavioural changes and performance of the employees ar work. This is because a leader or manager considered quality if he or she evaluates the relationship between leadership style and employee levels of organizational commitment. The type of leadership style is similar with transformational leadership style.

\section{The Relationship between Leadership Role and Change Management}

From the review done by the United Nation (2019), specific needs of the organization need to be tailored and informal mechanisms can structure dialogues and engagement with the staff as readiness assessments do not have to be huge and costly.

Among the critical success factors listed in the review is senior leaders need to contribute to the change. Apart from leadership by the executive head alone, a clear governance structure for change management-related reforms is also necessary. This is to ensure that the process can be influenced by the relevant stakeholders limited by their role and structure depending on organizational configurations and the type of reforms. Moreover, expertise or capacity in change management across staff is also required. The selection and use of change agents across an organization in a reform is critical as reforms that use change agents across an organization are twice as likely to have good depth across the key elements of change management United Nation (2019). Therefore, there are specific leadership styles or traits that are suitable for effective organizational change.

There is an increasing number of recognitions where most successful implementation of change is impacted by good leadership practices, styles and behaviours. There are some agreements among past researchers on significant role of leaders' behaviours towards change success. Strategic renewal is also seen as a consequence of leadership behaviours that build effective relationships with followers and engage them with the strategic vision and goals 
through high levels of involvement and participation (Kuipers et al, 2014; Higgs \& Rowland, 2011; Bamford \& Forrester, 2003).

Furthermore, Mwakisaghu (2019) studied how leadership act as strategic management change determinant. The adoption of changes by strategic management is build upon trust, organization culture, learning, team work communication and leading. This is in line with Atkinson (2015) view on strategic management changes can take place if there is effective leadership in the organization. The determinants stated by Mwakisaghu fits with Atkinson's view as it is necessary for leaders to provide a clear direction for the organization as it helps to motivate and drive the employees in the organization.

More in Mwakisaghu (2019), trust shows significant effect to determine the effectiveness of leadership. When the followers or subordinates trust their leader especially to the changes that to be brought in the organization, they tend to follow as they believe him or her may lead them to the right path either for themselves and/ or the organization. Other than that, leaders with strong leadership skills will shape a positive culture in the organization and thus, influences the behavior and attitude of the employees in the organization for the better (Ionescu, 2014; Schein, 2010). Both leaders and the employees should join training programs as further learning may improve their ability to perform well in their job. This can also help to facilitate the effective desired change implementation and at the same time enhance the productivity and performance of the employees. Lastly, Gilley, Dixon \& Gilley (2008) in Mwakisaghu (2019) indicated that leaders who wish to facilitate effective change in the organization should encourage employees to collborate and communicate with each other. Even the top management can learn and consider the strong points given by their employees.

\begin{tabular}{|l|l|l|l|}
\hline \multicolumn{1}{|c|}{ Author } & Year & \multicolumn{1}{|c|}{ Purpose } & \multicolumn{1}{c|}{ Findings } \\
\hline Kuipers et al & 2014 & $\begin{array}{l}\text { To find gaps of recent } \\
\text { literature on change } \\
\text { management in public } \\
\text { organizations. }\end{array}$ & $\begin{array}{l}\text { Both the institutional theory and the } \\
\text { general change management literature } \\
\text { are dominant. Authors suggest the areas } \\
\text { for future research into change } \\
\text { management within the public sector } \\
\text { should include at least seven particular } \\
\text { themes and angles across the context, } \\
\text { content process outcomes, and } \\
\text { leadership of sub-system,organizational } \\
\text { and sectoral change. }\end{array}$ \\
\hline $\begin{array}{l}\text { Higgs } \\
\text { Rowland }\end{array}$ & 2011 & $\begin{array}{l}\text { To explore the impact } \\
\text { of leaders' behaviors } \\
\text { on the successful } \\
\text { implementation of } \\
\text { change. }\end{array}$ & $\begin{array}{l}\text { There is evidence to support the view that } \\
\text { managing change and understanding the } \\
\text { complexity of the phenomenon plays a } \\
\text { significant role in ensuring successful } \\
\text { implementation. Furthermore, it has been } \\
\text { proven the relationship between leader } \\
\text { behaviors and the approach adopted to } \\
\text { change implementation. }\end{array}$ \\
\hline
\end{tabular}




\begin{tabular}{|c|c|c|c|}
\hline $\begin{array}{l}\text { Atkinson \& } \\
\text { Mackenzie }\end{array}$ & 2015 & $\begin{array}{l}\text { To demonstrate how } \\
\text { aligned leadership } \\
\text { with strategies can } \\
\text { shape high quality } \\
\text { performance cultures. }\end{array}$ & $\begin{array}{l}\text { The results for the business can be } \\
\text { immense once it has established and } \\
\text { aligned a strong leadership style with } \\
\text { strategies for continual improvement. } \\
\text { Business that develop a strong internal } \\
\text { leadership capability and culture will be } \\
\text { able to sustain any drive for change and } \\
\text { guarantee a competitive edge for the } \\
\text { future. }\end{array}$ \\
\hline Mwakisaghu & 2019 & $\begin{array}{l}\text { To explain how } \\
\text { strategic } \\
\text { management change } \\
\text { in organizations bring } \\
\text { positive change. }\end{array}$ & $\begin{array}{l}\text { Leadership is proven to be one of the } \\
\text { success factors to motivate and } \\
\text { continuously encourage and push them to } \\
\text { change. }\end{array}$ \\
\hline Gilley et al & 2008 & $\begin{array}{l}\text { To explore leadership } \\
\text { effectiveness in } \\
\text { driving change and } \\
\text { innovation. }\end{array}$ & $\begin{array}{l}\text { The perceived importance of specific } \\
\text { leadership skills and abilities necessary for } \\
\text { successful change and innovation. Thus to } \\
\text { enhance change effectiveness skills } \\
\text { organizations will be interested in } \\
\text { assessing and improving change and } \\
\text { innovation talent and abilities of leaders at } \\
\text { all levels, including the executive. Given } \\
\text { the critical nature of change in the global } \\
\text { economy, leadership and management } \\
\text { development should focus on change skills } \\
\text { and abilities. }\end{array}$ \\
\hline
\end{tabular}

Table 1: Literature matrix on the relationship between leadership role and change management

\section{Discussion and Conclusion}

Based on findings, researcher synthesizes some opinions and ideas gathered from literature reviews from different scholars and academicians.

From the past researches reviewed in this paper, I can conclude that change management is crucial in every organization especially in facing the challenges in 21st century as the issues nowadays are not as conventional as the last decade. Organizations must adopt changes within to meet the fast-changing environment especially in business and also in serving public or communities.

Every challenges and issues varied and the approach to overcome need to be tailor-made. In approaching towards effective problem solving and decision making, the leader or manager must first identify the issues and need to educate and convince the subordinates or followers to accept organizational change. Their acceptance towards change proves that the manager applies an effective leadership for managing change. To be a better leader, one has to undergo training so that the skills are improving. It is even better to include the employees as well to join the training as it can motivate them and hence, improving the productivity of the organization. 
Leadership style varies according to individuality of the manager himself, but it brings similar vision of bringing change among the subordinates in the organization. The topic of leadership is highly discussed among scholars and it is still being debated even in this century. This also proves that good and effective leadership results in better management in organizations especially for promoting change and maintain the openness culture.

\section{Conclusion}

This paper aimed to evaluate how prior researches had been dealing with organizational change in recent years taking in account leadership role. The first purpose was achieved with finding from the research reveals the leadership dimensions suggested by prior researchers. The key findings indicated that Transformational Leadership emerged as one of the important dimensions in recent studies. There are indications that proof a strong relationship between effective leadership and significant impacts on successful organizational management. Hence, the second purpose of this study was met where the variables could be practically used as corporate future direction indicator by top management. In closing, our objectives for this research have been achieved. Despite these findings, we hope to trigger more studies on this area as we believe that the identified dimensions are a strong indicator of a variety of different industries, yet we do not want to limit to them. More research can be carried out to uncover other moderators and illustrating how these performance measures affects corporate future direction even more clearly in future extensions of this research.

\section{Acknowledgements}

This work was supported/funded by the Ministry of Higher Education under Fundamental Research Grant Scheme (FRGS/1/2019/SS03/UTM/02/8).

\section{References}

Atkinson, P., \& Mackenzie, R. (2015). Without leadership there is no change. Management Services, 59(2), 42-47.

Awuor, E., \& Kamau, E. (2015). Analysis of the role of leadership styles in managing change in organizations: a case study of Kenya tea development agency (KTDA). Journal of Resources Development and Management, 10, 1-15.

Bamford, D. R., \& Forrester, P. L. (2003). Managing planned and emergent change within an operations management environment. International Journal of Operations \& Production Management, 23 (5), 546-564.

Barber, M., Donnelly, K., \& Rizvi, S. (2013). An avalanche is coming: higher education and the revolution ahead. Institute for Public Policy Research.

Belias, D., \& Koustelios, A. (2014). The impact of leadership and change management strategy on organizational culture. European Scientific Journal, 10(7), 451-470.

Carter, M. Z., Armenakis, A. A., Feild, H. S., \& Mossholder, K. W. (2012). Transformational leadership, relationship quality, and employee performance during continuous incremental organizational change. Journal of Organizational Behavior, 34(7), 942-958.

Darwish, S., Alzayed, S., \& Ahmed, U. (2020). How Women in Science can Boost Women's Entrepreneurship: Review and Highlights. International Journal of Innovation Creativity and Change, 14(1), 453-470.

Dike, V. E., Odiwe, K., \& Ehujor, D. M. (2015). Leadership and management in the 21st century organizations: a practical approach. World Journal of Social Science Research, 2(2), 139159. 
Faupel, S., \& Sub, S. (2018). The effect of transformational leadership on employees during organizational change-an empirial analysis. Journal of Change Management, DOI: 10.1080/14697017.2018.1447006

Ganta, V. C., \& Manukonda, J. K. (2014). Leadership during change and uncertainty in organizations. International Journal of Organizational Behaviour \& Management Perpectives, 3(3), 1183.

Gerwing, C. (2016). Meaning of change agents within organizational change. Journal of Applied Leadership and Management, 4, 21-40.

Gilley, A., Dixon, P., \& Gilley, J. W. (2008). Characteristics of leadership effectiveness: implementing change and driving innovation in organizations. Human Resource Development Quarterly, 19(2), 153-169.

Hao, M. J., \& Yazdanifard, R. (2015). How effective leadership can facilitate change in organizations through improvement and innovation. Global Journal of Management and Business Research, 15(9), 1-6.

Higgs, M. J., \& Rowland, D. (2011). What does it take to implement change successfully? A study of the behaviors of successful change leaders. Journal of Applied Behavioral Science, 47(3), 309-335.

Holten, A. L., \& Brenner, S. O. (2015). Leadership style and the process of organizational change. Leadership \& Organization Development Journal, 36(1), 2-16.

Hussain, S. T., Lei, S., Akram, T., Haider, M. J., Hussain, S. H., \& Ali, M. (2018). Kurt Lewin's change model: a critical review of the role of leadership and employee imvolvement in organizational change. Journal of Innovation \& Knowledge, 3(3), 123-127.

Ionescu, V. (2014). leadership, culture and organizational change. Manager, (20), 65-71.

Kuipers, B. S., Higgs, M. J., \& Kickert, W. (2014). The management of change in public organisations: a literature review. Public Administration, 92(1), 1-20.

Mansaray, H. E. (2019). The role of leadership style in organisational change management: a literature review. Journal of Human Resource Management, 7(1), 18-31.

Mwakisaghu, J. K. (2019). Strategic management change. International Journal of Advanced Research in Management and Social Sciences, 8(5), 8-22.

Porras, J., \& Robertson, P. (1992). Organizational development: theory, practice, research. In M.D. Dunnette \& L. M. Hough (Eds.) Handbook of Organizational Psychology, 3, 719-822.

Schein, E. H. (2010). Organizational culture and leadership (Vol. 2). John Wiley \& Sons.

United Nation. (2019). Review of change management in United Nations system organizations: Report of the Joint Inspection Unit. Geneva, Switzerland: Author.

Wanza, S. L., \& Nkuraru, J. K. (2016). Influence of change management on employee performance: a case study of University of Eldoret, Kenya. International Journal of Business and Social Science, 7(4), 190-199. 